\title{
Arginine Metabolism by Spiroplasma citri
}

\author{
By R. TOWNSEND \\ John Innes Institute, Colney Lane, Norwich NR4 $7 \mathrm{UH}$
}

(Received 15 October 1975; revised 22 December 1975)

\section{INTRODUCTION}

The newly identified organism Spiroplasma citri (Saglio et al., 1973), the leafhoppertransmitted agent of stubborn and little-leaf diseases of citrus (Markham et al., 1974), exhibits many properties characteristic of fermentative mycoplasmas, including the ability to use glucose and fructose as energy substrates. It has also been reported that it does not hydrolyse arginine (Bové et al., 1973; Saglio et al., 1973, 1974). However, the pH fluctuations observed in spiroplasma cultures supplemented with arginine suggested that $S$. citri might be able to metabolize this amino acid.

\section{METHODS}

Culture. Spiroplasma citri, little-leaf strain (SP-A), was grown in a basal spiroplasma medium (BSM) containing: $2 \cdot \mathrm{I} \%$ (w/v) PPLO broth (Difco), $0.5 \%(\mathrm{w} / \mathrm{v}$ ) yeast extract (Oxoid), I \% (w/v) sodium chloride, I $5 \%(\mathrm{v} / \mathrm{v})$ horse serum no. 6 (Wellcome Reagents Ltd, Beckenham, Kent, heated to $60{ }^{\circ} \mathrm{C}$ for $30 \mathrm{~min}$ before use), phenol red (10 $\left.\mu \mathrm{g} \mathrm{ml}^{-1}\right), 0.025 \%$ thallous acetate; and supplemented as indicated with $0.1 \%$ glucose, $0.1 \%$ fructose, or $0.42 \% \mathrm{~L}$ arginine monohydrochloride. When necessary $\mathrm{I} \%(\mathrm{w} / \mathrm{v})$ agar was used to solidify this medium. The $\mathrm{pH}$ of the medium, normally about $7 \cdot 6$, was adjusted, when required, with I M-hydrochloric acid or I M-sodium hydroxide. Cultures were incubated at $32{ }^{\circ} \mathrm{C}$.

Measurement of $\mathrm{pH}$ and assay of ammonia. Daily measurements of $\mathrm{pH}$ and ammonia concentration were made on samples $(0.25 \mathrm{ml})$ from $10 \mathrm{ml}$ cultures. The $\mathrm{pH}$ was measured with a Pye Ingold micro-electrode (Pye Unicam, Cambridge). Ammonia was assayed by the Nessler method (Vogel, 196r), following removal of the acid-insoluble material by adding an equal volume of $10 \%$ (w/v) trichloroacetic acid (TCA), and 20-fold dilution in distilled water. Extinction was measured at $4 \mathrm{I} 2 \mathrm{~nm}$ with reference samples prepared from uninoculated medium.

Electrophoresis. One-dimensional electrophoresis of the amino acids in the cultures was carried out by the flat-plate technique of Trim \& Dickerson (1974) using Whatman $3 \mathrm{MM}$ paper and a buffer solution, $\mathrm{pH} 6.5$, containing $10 \%(\mathrm{v} / \mathrm{v})$ pyridine and $0.4 \%$ acetic acid. Samples $(0.1 \mathrm{ml})$ of $2 \mathrm{ml}$ cultures grown in BSM supplemented with combinations of sugars, $0.42 \%(20 \mathrm{mM}) \mathrm{L}$-arginine monohydrochloride and L-[U-14 $\mathrm{C}]$ arginine monohydrochloride (318 $\mathrm{mCi} \mathrm{mmol}^{-1}$, about $5 \mu \mathrm{Ci} \mathrm{ml}^{-1}$ ), were added to an equal volume of $10 \% \mathrm{TCA}$, centrifuged, and Io $\mu$ l portions of the supernatant solution spotted at the anode end of the paper. A potential gradient of $33 \mathrm{~V} \mathrm{~cm}^{-1}$ was applied for $3 \mathrm{~h}$. Spots were located by spraying with ninhydrin $(0.2 \%$ in acetone) and identified by comparison with amino acid standards and samples of uninoculated media run under the same conditions. Subsequently the amino acid spots on the electrophoresis papers were cut out, placed in scintillation vials with $5 \mathrm{ml}$ of scintillation mixture [containing $4 \mathrm{~g}$ 2,5-diphenyloxazole (PPO) and $50 \mathrm{mg} \mathrm{I,4-di-2-}$ 
(5-phenyloxazolyl) benzene (POPOP) in I 1 toluene] and counted for $5 \mathrm{~min}$ in a liquid scintillation counter.

Measurement of growth. Growth of $S$. citri was assessed by colony counts made on Io $\mu \mathrm{l}$ samples of serial 10 -fold dilutions of the cultures. Plates were incubated for 7 days and counted after staining with Dienes' stain (Scriba, 1968).

\section{RESULTS}

\section{Ammonia production}

Spiroplasmas grew well in BSM supplemented with glucose and fructose: the acid produced caused a fall in $\mathrm{pH}$ from 7.6 to below 5.4 in 4 days without any detectable liberation of ammonia. If $20 \mathrm{~mm}$-arginine was also added, up to $30 \mathrm{~mm}$-ammonia was released, which completely neutralized the acid, producing a characteristic $\mathrm{V}$-shaped pattern of $\mathrm{pH}$ fluctuation (Fig. I). Supplementation of BSM with arginine alone resulted in the release of less than $6 \mathrm{~mm}$-ammonia accompanied by a small rise in $\mathrm{pH}$. Added urea was not metabolized.

Strains of $S$. citri from Morocco (R8-A2) and California (CI89) produced pH changes similar to those shown in Fig. I and consistently gave rise to more ammonia when sugars were present in the medium.

\section{Electrophoresis}

The amino-acid pattern of cultures containing labelled arginine with excess unlabelled amino acid and sugars showed that, after 2 to 3 days' incubation, the concentration of arginine began to fall steadily accompanied by the appearance of increasing amounts of ornithine. It was not possible to determine visually if there was also an increase in citrulline concentration, because the acid-soluble fraction of BSM contained material with the same mobility as citrulline.

Radioactivity was only associated with the arginine, ornithine and citrulline spots. There was good correlation between the decrease in counts per minute (c.p.m.) in the arginine spots and the increase in c.p.m. in ornithine and citrulline spots, after allowing for the calculated loss in radioactivity due to the formation of carbamyl phosphate and the presence of 5 to $10 \%$ of the initial radioactivity in the acid-insoluble fraction. In all experiments, after 8 days, at least $20 \%$ of the total radioactivity was in the form of $\left[{ }^{14} \mathrm{C}\right]$ citrulline indicating that the breakdown of arginine to ornithine was incomplete. Even when the incubation period was extended to 14 days, there was no decline in the concentration of $\left[{ }^{14} \mathrm{C}\right]$ citrulline. In cultures supplemented with sugars and $\left[{ }^{14} \mathrm{C}\right]$ arginine $\left(5 \mu \mathrm{Ci} \mathrm{ml}{ }^{-1}\right)$ but no unlabelled amino acid, the degradation of arginine was much faster, complete breakdown taking only $48 \mathrm{~h}$. However, up to $25 \%$ of the total radioactivity still remained in the form of $\left[{ }^{14} \mathrm{C}\right]$ citrulline. When the medium was supplemented with arginine alone, the organisms failed to use more than $20 \%$ of the labelled amino acid, despite extended incubation, but still produced the same pattern of incomplete degradation.

\section{Effect of $\mathrm{pH}$ on ammonia production}

Arginine hydrolysis was not stimulated at any particular $\mathrm{pH}$, but in media supplemented only with arginine it was slightly enhanced at initial values between $\mathrm{pH} 7 \cdot 2$ and $\mathrm{pH} 6.6$, when up to ro mM-ammonia was produced. Adjusting the starting $\mathrm{pH}$ of medium supplemented with sugars and arginine to $\mathrm{pH} 7$ resulted in the release of nearly $32 \mathrm{~mm}$-ammonia. Below this $\mathrm{pH}$, progressively less ammonia was produced although the characteristic $\mathrm{V}$-shaped pattern of $\mathrm{pH}$ fluctuation was maintained. At initial values below $\mathrm{pH} 5 \cdot 5$, the organism did not grow. 


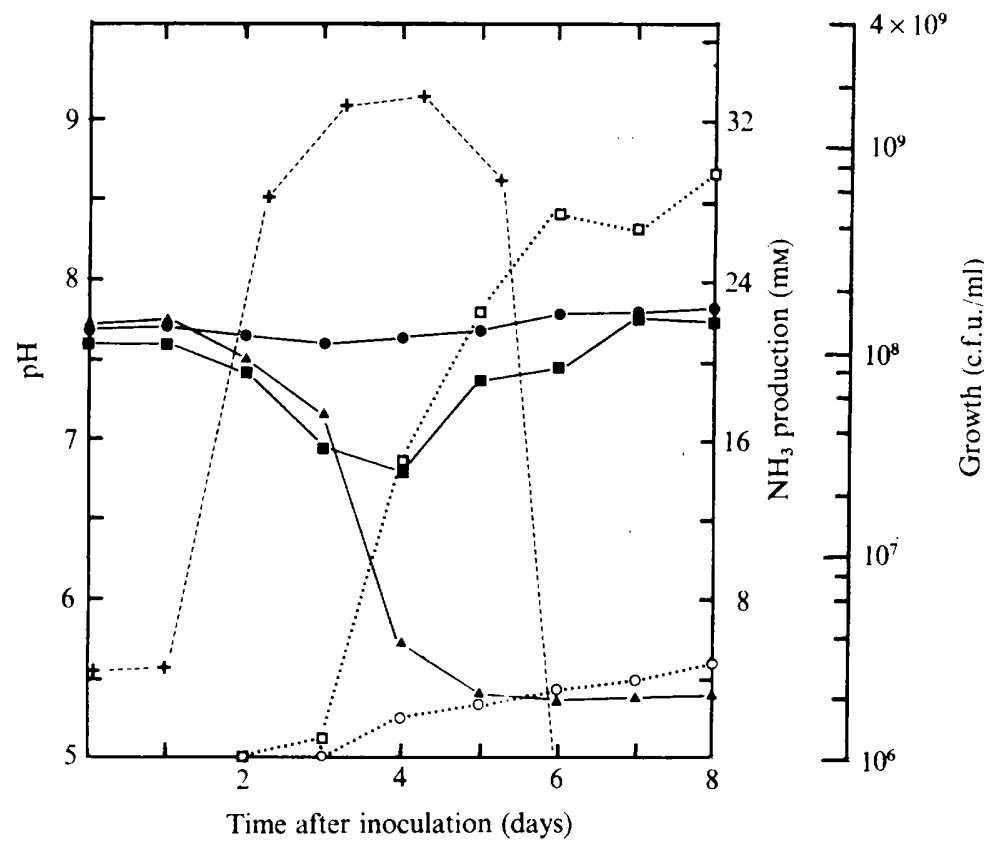

Fig. 1. Changes in pH (solid symbols) and ammonia production (open symbols) in cultures of $S$. citri (SP-A) grown in BSM supplemented with arginine (O), arginine and sugars (i), and sugars alone ( $\mathbf{A})$; and growth of SP-A in BSM with sugars as measured by colony forming units (c.f.u) $(+)$.

\section{DISCUSSION}

The increase in concentration of ornithine and citrulline as the degradation of arginine proceeded, and the absence of urease activity, indicated that the arginine dihydrolase pathway was operative in S. citri. In non-fermentative mycoplasmas, the course of this pathway varies according to the metabolic activity of the organisms. In actively growing mycoplasma cells, the constant requirement for ATP biases the combined reactions towards carbamyl phosphate formation and ensures the complete breakdown of citrulline to ornithine. When the cells enter the stationary phase, the greatly decreased requirement for ATP causes citrulline breakdown to stop but arginine degradation continues and citrulline accumulates (Schimke \& Barile, 1963; Smith, I97I). In cultures of S. citri, citrulline accumulated in both growing and stationary-phase cultures and this decreased the formation of ATP and liberation of $\mathrm{NH}_{3}$ by the arginine dihydrolase pathway. Complete metabolism of $0.42 \%(20 \mathrm{mM}-$ arginine) hydrochloride by this pathway would liberate nearly $40 \mathrm{~mm}$-ammonia in the culture. It appeared that the incomplete degradation of citrulline to ornithine, which occurred even"under optimum growth conditions, reflected the limited contribution of this pathway to the overall energy requirements of $S$. citri.

Complete utilization of arginine only occurred when an alternative energy source in the form of glucose or fructose was present to encourage growth. This may explain why previous workers failed to detect arginine hydrolysis in S. citri by the standard test of Aluotto et al. (1970) in which arginine was the only energy source. The poor growth of spiroplasmas in the medium used for this test resulted in insufficient ammonia being released to cause a detectable change in the colour of the phenol red indicator. P. Saglio has since repeated the 
arginine hydrolysis tests on $S$. citri and has confirmed that this organism hydrolyses arginine (unpublished results).

The author is grateful to Drs M. J. Daniels, P. G. Markham and P. Saglio for advice and valuable discussions.

\section{REFERENCES}

Aluotro, B. B., Wittler, R. G., Williams, C. O. \& Faber, J. E. (1970). Standardized bacteriologic techniques for the characterization of Mycoplasma species. International Journal of Systematic Bacteriology 20, 35-58.

Bové, J. M., Saglio, P., Tully, J. G., Freundt, E. A., Lund, Z., Pillot, J. \& Taylor-Robinson, D. (I973). Characterization of the mycoplasma-like organism associated with 'Stubborn' disease of citrus. Annals of the New York Academy of Sciences 225, 462-470.

Markham, P. G., Townsend, R., Bar-Joseph, M., Daniels, M. J., Plaskitt, A. \& Meddins, B. M. (1974). Spiroplasmas are the causal agents of citrus little-leaf disease. Annals of Applied Biology 78, 49-57.

Saglio, P., Davis, R. E., Dalibart, R., Dupont, G. \& Bové, J. M. (1974). Spiroplasma citri: L'espèce type des spiroplasmes. In Les Mycoplasmes de l'Homme, des Animaux, des Vegetaux et des Insectes, INSERM International Congress, pp. 27-34. Edited by J. M. Bové and J. F. Duplan. Paris: INSERM.

Saglio, P., L'Hospital, M., Laflèche, D., Dupont, G., Bové, J. M., Tully, J. G. \& Freundt, E. A. (1973). Spiroplasma citri gen. and sp.n.: a mycoplasma-like organism associated with 'Stubborn' disease of citrus. International Journal of Systematic Bacteriology 23, 191-204.

SCHIMKE, R. T. \& BARLIE, M. F. (1963). Arginine metabolism in pleuropneumonia-like organisms isolated from mammalian cell culture. Journal of Bacteriology 86, 195-206.

SCRIBA, M. (I968). Experiments to eliminate mycoplasmas from tissue cultures by means of antibiotics. Zeitschrift für medizinische Mikrobiologie und Immunologie 154, 267-276.

Sмrтн, P. F. (I971). The Biology of Mycoplasmas, pp. 99-107. New York: Academic.

Trim, A. R. \& Dickerson, P. E. (1974). Fractionation of unlabelled and radioactive nucleotides by ionophoresis in two dimensions on a flat plate. Analytical Biochemistry 57, 93-99.

VoGEL, A. I. (196r). Quantitative Inorganic Analysis, 3rd edn, pp. 783-784. London: Longmans. 